$4 \quad$ Andrea Kodym ${ }^{A, B, C}$, Mirini Lang ${ }^{A}$ and John Delpratt ${ }^{A}$

5

$6{ }^{A}$ Faculty of Science, The University of Melbourne, Burnley Campus, Richmond, VIC 3121,

7 Australia

$8{ }^{\text {B }}$ Core Facility Botanical Garden \& Department of Pharmacognosy, University of Vienna,

91090 Vienna, Austria

$10{ }^{C}$ Corresponding author

Dr Andrea Kodym

13 Core Facility Botanical Garden \& Department of Pharmacognosy,

14 University of Vienna

1090 Vienna, Austria

Phone: +436606875409

17 Email: andrea.kodym@univie.ac.at

Past:

Faculty of Science

The University of Melbourne, Burnley Campus,

500 Yarra Boulevard, Richmond, VIC, 3121

\title{
Mirini Lang
}

Faculty of Science

This is the author manuscript accepted for publication and has undergone full peer review but has not been through the copyediting, typesetting, pagination and proofreading process, which may lead to differences between this version and the Version of Record. Please cite this article as doi: $10.1111 /$ emr.12209

This article is protected by copyright. All rights reserved 
The University of Melbourne, Burnley Campus,

Email: mirini@ghostgum.com.au

John Delpratt

Faculty of Science

The University of Melbourne, Burnley Campus,

500 Yarra Boulevard, Richmond, VIC, 3121

Phone: 0392506800

Email: ceciljd@unimelb.edu.au

\section{Acknowledgements}

Thanks to Michael Garrett, Bicheno Nursery in Tasmania, for sharing his knowledge in propagation of Austral Bracken from spores and to David Carew, Melbourne Water for sharing his ideas and visions. Their input was instrumental in developing a successful acclimatisation and sporophyte development technique. Thanks to John Thomson from the RBG Sydney for providing spores and information for initial germination studies. The authors highly appreciate the support by the Fern Society of Victoria for collecting Austral Bracken spores and for providing contact details. Thanks to the staff of Melbourne Water, Fulton Hogan Ecodynamics Joint Venture and Woods Environmental Services for their cooperation in regards to field plantings and to Australian Ecosystems for running acclimatisation experiments. Thanks also go to the staff of the Conservation Biotechnology Unit of the Royal Botanic Gardens, Kew for sharing their expertise on fern propagation and encapsulation. This project was in large part funded by Melbourne Water. The project was further supported by The Frank Keenan Scholarship and The James John Woodward Prize

54 from the University of Melbourne awarded to Mirini Lang. 
Article type : Short note

Propagation by partial tissue culture

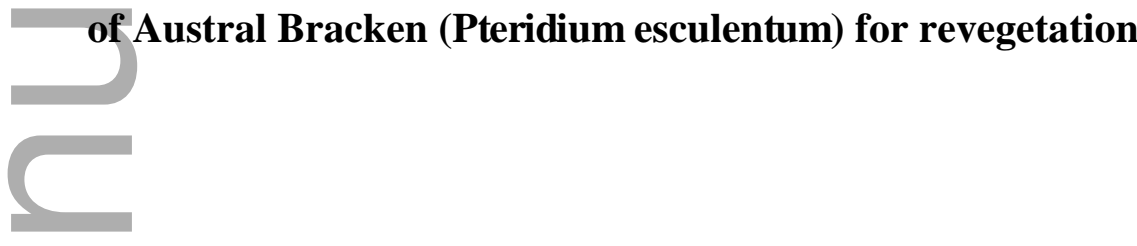

Summary

Austral Bracken (Pteridium esculentum) is a native fern common in many Australian ecosystems and is needed in large numbers for revegetation projects. The main limiting factor for the propagation of locally sourced material is spore availability. A mass propagation system was developed by combining tissue culture and nursery based systems. Spores collected over the summer months from wild populations were germinated in vitro on $1 / 2 \mathrm{MS}$ medium containing $0.15 \% \mathrm{w} / \mathrm{v}$ activated charcoal. Gametophytes were rapidly multiplied on the same medium. In vitro sporophyte development was unreliable although sometimes prolific. However, gametophytes transferred to a pine bark potting medium with added coir, on a capillary bed in a fog house, produced sporophytes reliably. Across different seasons and populations, 75 to $100 \%$ of the gametophyte explants developed sporophytes within about nine weeks. Three hundred propagated ferns planted into two field sites within their provenance origins had a survival of 92 and $95 \%$ respectively, three or four months after planting. This report delivers a ready to use and reliable protocol for the mass propagation of bracken fern of local origin to the revegetation industry. 
Key words

In vitro, spores, micropropagation, bracken fern, revegetation

\section{Introduction}

Pteridium esculentum (G. Forst.) Cockayne, commonly known as Austral Bracken, is a temperate and tropical terrestrial fern that grows in a wide range of environments. It is one of the most common plants in Australia and found in all states (Jones and Clemeshea 1980). In the greater-Melbourne area, Austral Bracken is the most frequently listed plant in northeastern Ecological Vegetation Classes (EVCs) and the third most frequent in the southeastern EVCs (D. Robertson, pers. comm., 2013). The plant has earned a reputation as a problematic species on farms because the fronds are poisonous to livestock when ingested in large quantities (Low and Thomson 1990) and because it invades cleared, disturbed and recently burned areas (Thomson et al. 1986; Smith et al. 1994). However it plays numerous roles by providing habitat to small native animals (Cardinia Shire Council 2015), preventing erosion, suppressing exotic grasses and having a capacity to survive drought, repeated grazing and fire (Jones and Clemesha 1980, McGlone et al. 2005). This makes it important in the rehabilitation of degraded and difficult sites (e.g. floodway channels, road verges) where maintenance levels need to be kept to a minimum or water quality requires protection.

While Austral Bracken is a very common and prolific plant in its natural environment, where it mainly spreads vegetatively by rhizomes, its propagation using vegetative nursery-based systems is slow and unreliable (Australian Plants Society Maroondah Inc. 2001). Vegetative propagation requires at least $30 \mathrm{~cm}$ long rhizome parts with young vigorous lateral buds and an apex shoot (Jones 1987). Although sexual propagation is straightforward (M. Garrett, pers. comm., 2013) it is difficult to source sufficient spores because Austral Bracken is erratically fertile in Australia. For these reasons, a project was initiated by Melbourne Water to develop effective propagation protocols for Austral Bracken by tissue culture.

Tissue culture has been used successfully for the propagation of many commercially available ferns (Fernandez and Revilla 2003) and ferns of interest for conservation (Barnicoat et al. 2011). The in vitro propagation of Austral Bracken from Western Australia has been published recently (Willyams and Daws 2014). Although they reported that the culture of gametophytes (prothallus) was prolific, the formation of sporophytes was unreliable and highly variable between spore lines and culture vessels. 
The aim of this technical trial was to develop a reliable method for producing sporophytes in Austral Bracken to allow the large scale propagation of material of local origin for revegetation.

\section{Methods}

Spore collection and germination of spores in vitro

Spores of Austral Bracken were collected from five Victorian populations: 1) Leversha Reserve (Montrose) in December 2011; 2) Bunarong Park (Frankston) in December 2011; 3) Jamieson in January 2013; 4) Kurth Kiln Regional Park (Gembrook) in May 2013; 5) Anglesea in December 2013 (see App 1 for map) In addition to these Victorian collections, spores collected at the Wakehurst Parkway, NSW in May 2001 were provided by the Royal Botanic Gardens Sydney.

Spores were sterilised in $0.5 \%(\mathrm{w} / \mathrm{v})$ sodium dichloroisocyanurate (Sigma) and a few drops of Tween 20 (Sarasan et al. 2006) on a shaker for $35 \mathrm{~min}$ and then rinsed three times in sterile deionised water. Spores were cultured in Petri dishes with basal medium (BM). The BM was $1 / 2$ MS medium (Murashige and Skoog 1962), full MS vitamins, 2\% (w/v) sucrose, 0.2\% $(\mathrm{w} / \mathrm{v})$ gelrite (Sigma) and $0.15 \%(\mathrm{w} / \mathrm{v})$ activated charcoal. Cultures were maintained at $22{ }^{\circ} \mathrm{C}$ $+/-2{ }^{\circ} \mathrm{C}$ under $40 \mu \mathrm{mol} \mathrm{m} \mathrm{m}^{-1} \mathrm{~s}^{-1}$ light with a $16 \mathrm{~h}$ photoperiod provided by fluorescent lamps (Sylvania Grolux T8 36W).

Propagation of gametophytic tissue in vitro

After about 5 weeks the plant material was subcultured. Gametophytes with occasional small sporophytes were macerated in a vial with sterile water using a glass rod. The suspension was evenly spread across new Petri dishes containing BM. The populations were maintained as separate lines at all times and subcultured regularly.

\section{Sporophyte development}

In mid-April 2013 a trial with gametophytes of Frankston origin was set up to induce sporophytes in the fog house. Sealed Petri dishes of gametophytes were placed in the fog 
house to enable acclimatisation to the changed light and temperature conditions prior to deflasking. After one week the gametophytes were carefully cleaned of the tissue culture medium in warm water and then separated into small clumps and arranged in half-tray punnets (335 x $140 \times 55 \mathrm{~mm}$ ) (App. 2 a). Two Petri dishes with gametophytes were used to plant one half-tray with 4 explants per row, 10 rows per half-tray. The explants were grown in two types of potting mix: a) general potting/coir mix $(1: 1 \mathrm{v} / \mathrm{v})$ or b) perlite/coir $(1: 3 \mathrm{v} / \mathrm{v})$. Three half-trays were planted per treatment. The general potting mix was 4 parts medium pine bark to 1 part coarse sand by volume. Coir (Grodan coir peat, standard medium grade) and perlite (Exfoliators Premium Perlite, Coarse grade) were both supplied by Duralite Horticultural Supplies (Braeside, Vic, Australia). Both potting mixes contained $4 \mathrm{~g} / \mathrm{l}$ Green Jacket slow release fertiliser (NPK: 16.5: 4.1: 9.6) by Debco (Tyabb, Vic, Australia).

The half-trays were placed on a portable capillary bed (CapPlus Tray by Autopot Systems) and watered in. Three hours later CitroFresh spray (CitroLife of GCM Technologies Pty Ltd, Melbourne, Australia) was applied to avoid mould. Its application continued once a week for the entire trial. The fog house conditions were $90 \%$ shade, automatic fog to create $90 \%$ relative humidity, $24{ }^{\circ} \mathrm{C}$ bench heating and hand watering. After 9 weeks sporophytes identified with the naked eye were recorded. The percentage of explants growing into sporophytes was calculated for each half-tray (based on 40 explants) and then averaged over the number of replications.

After 12 weeks in the fog house the half-tray punnets were moved from the capillary system to a glasshouse with $70 \%$ shading, overhead watering and bench heating at $24{ }^{\circ} \mathrm{C}$. The glasshouse was ventilated when the ambient air temperature reached $25^{\circ} \mathrm{C}$. After one week the sporophytes were separated as much as possible and potted into forestry tubes using the general potting/coir mix. Tubes could contain one or more sporophytes depending on the plant size and how densely clustered they were. The number of tubes potted up from each half-tray was recorded.

Testing the reliability of the new protocol

In order to evaluate how reliable the above protocol is for inducing sporophytes over different seasons and for different populations, five more trials were set up in the fog house in May, 
June, July and November 2013 using gametophytes from two populations (Frankston and Gembrook). Only general potting/coir mix was used.

Growing-on in the nursery

The sporophytes coming from various acclimatisation experiments were grown in forestry tubes $(50 \times 50 \times 120 \mathrm{~mm}, 0.2$ 1) and round pots $(130 \mathrm{~mm}, 11)$, all from Garden City Plastics (Monbulk, Vic, Australia). The general potting/coir mix (1:1 v/v) with $4 \mathrm{~g} / \mathrm{l}$ Green Jacket fertiliser was used. The plants were kept in the glasshouse for two weeks before being transferred to an outdoor shade area (70\% beige shade cloth overhead and $50 \%$ black shade cloth on three walls) with overhead watering.

Field plantings

Two Melbourne revegetation sites with very different site and climate conditions were chosen: Baxter and Montrose (App.1). Austral Bracken was planted on the $13^{\text {th }}$ May and $25^{\text {th }}$ of June 2013 respectively using material of provenance origin (Frankston and Montrose populations respectively). The plants originated from pre-trials and were hardened off in the full sun for 1-2 weeks before the field planting occurred. Two hundred plants were planted at Baxter and 100 at Montrose by professional planting crews following their routine procedures. The plants were then tagged and a location stake placed beside each plant. They were not watered in after planting.

At Baxter (App. 2b), a newly constructed pond system was revegetated. Site preparation included herbicide weed treatment. Tube stock was planted at a distance of $1.7 \mathrm{~m}$ to $16 \mathrm{~m}$ from the water's edge. No weed mats or plant guards were used. However, spraying with Garlon (active ingredient triclopyr) was carried out regularly to control broadleaf weeds. The Montrose planting (App. 2c) was along a creek in a degraded forest, which includes Austral Bracken in the understorey. Weed mats and plastic tree guards (Suregro, Dingley, Vic, Australia) were used for each plant.

At both sites, the height of each Austral Bracken was measured from the ground to the distal end of the longest green frond part. The vigour of plants was assessed on the presence of croziers. Plant assessments were repeated in spring, at the end of September 2013 (Baxter approx. 4.5 months, Montrose 3 months after planting). 


\section{Results}

Spore collection and germination of spores in vitro

In all six spore collections abundant germination occurred after 1 to 2 weeks, demonstrating high viability. Gametophytes could be seen with the naked eye as early as 6 days after sowing. Spores sown more densely developed smaller gametophytes than those sown sparsely. Gametophytes were ready for subculturing after 4 to 5 weeks.

Propagation of gametophytic tissue in vitro

In all six lines, macerated gametophytes regrew quickly and covered the Petri dish uniformly in a thin layer within 4 to 5 weeks. Sporophytes could cover the whole Petri dish but generally they appeared in very low numbers or were altogether absent.

Sporophyte development

The first sporophytes developed in the fog house after about 3 weeks. After 9 weeks, the average percentage of explants producing sporophytes was $99 \%$ for both potting media (Tab. $1 ; 22$. April).

The trial was stopped by week 13, when the sporophytes had grown into such a dense mass that mould was beginning to cause sporophyte deaths. Trays should have been removed from the fog house earlier, as sporophyte numbers started to drop. The number of tubes obtained from the small explants on a general potting/coir mix was $121 \pm 16 \mathrm{SE}$ and $88.3 \pm 4.4 \mathrm{SE}$ on perlite/coir. Survival of plants transferred into tubes was $100 \%$ after 2 weeks in the greenhouse.

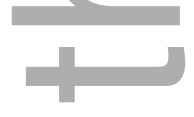

Testing the reliability of the new protocol

The developed protocol for the induction of sporophytes of Austral Bracken proved to be highly reliable across different seasons and populations with 75 to $100 \%$ of the gametophyte explants producing sporophytes (App. 2d and Tab. 1). The sporophytes were potted on before they grew into dense stands, as they were susceptible to fungal infections and could suddenly collapse. The time in the fog house could range from 55 to 84 days and the final evaluations were carried out after 61 to 89 days, both depending on the speed of development. Plants 
were ready for potting after one week in the greenhouse. The total time required from in vitro transfer to greenhouse pots ranged from 9 to 13 weeks.

Growing-on in the nursery

Pot size and shape influenced the bracken's growth. In the narrow forestry tubes, the rhizomes were soon constricted and the containers filled with fibrous roots, which made them prone to drying out. Overhead watering was often insufficient, not penetrating throughout the potting mix. In comparison, plants in the wider, round pots continued to grow vigorously.

Field Plantings

High survival was recorded after the winter in both field sites. At the Baxter site, $95 \%$ of the plants had survived. Plants that had died were often located in small depressions that had been flooded at times. At the Montrose site survival was $92 \%$. Some plants had been partially eaten leaving only the rachis and stipe remaining. Slugs and caterpillars were observed during monitoring and were probably the cause of the damage.

Plants were generally smaller in the spring review than at the time of planting. The old fronds had died back during winter and the new growth was still small. Their average height at planting was 288 and $270 \mathrm{~mm}$ for Baxter and Montrose respectively, and 203 and $232 \mathrm{~mm}$ in September. At the time of planting, new croziers were counted on $86 \%$ of the plants at Baxter (mid-May) and 62\% at Montrose (late June). In September, plants at the open, sunny Baxter site were more prolific than at the tree covered and cooler Montrose site. New crosiers were counted on $91 \%$ of plants at Baxter and $42 \%$ at Montrose.

\section{Discussion}

A reliable and robust method was developed to propagate Austral Bracken populations with low availability of spores. This overcame a serious bottleneck to producing planting material of local origin for revegetation projects. To what extent provenance origin plays a role in such a widely distributed species is unknown, but research has shown that populations differ at least in regard to cyanogenic phenotypes and the content of ptaquiloside (Low and Thomson, 1990; Smith et al. 1994). The propagation method combined a tissue culture system for spore germination and gametophyte multiplication, then a fog house capillary bed nursery environment for sporophyte development. The protocol (as summarised in Appendix 3) worked well on several populations and all year round in Melbourne, having an average 70 
to $100 \%$ sporophyte development success (based on the percentage of explants producing sporophytes). In vitro derived plants were healthy and vigorous and showed 95 and $92 \%$ field survival in the first spring in a wetlands project and in a creek-side erosion control project.

Spores from five Victorian populations were collected over two years, but only one collection (Gembrook) would have provided sufficient spores for regular nursery propagation. While locating sporulating plants in the field was rare, December and January were the most likely months in Victoria for successful collections. Austral Bracken spores could be germinated, and gametophytes multiplied easily, on a plant tissue culture medium. Spores from all collections were found to be viable. Storing spores at $4{ }^{\circ} \mathrm{C}$ over a desiccant was a very efficient technique because spores stored this way were still viable after 10 years. This result showed that Austral Bracken spores are long-lived, similar to P. aquilinum spores (Dyer 1989).

When using tissue culture for the propagation of ferns, they commonly progress from the gametophyte stage to the sporophyte stage in vitro. Acclimatisation occurs when ferns are already at the sporophyte stage (Fernandez and Revilla 2003; Somer et al. 2010; Menendez et al. 2011). The pathway from gametophytes to sporophytes in vitro is influenced by a wide range of culture conditions such as the frequency of transfer, nutrient levels and the maceration of gametophytes, but can be problematic in some species (Menendez et al. 2011; Fernandez and Revilla 2003). In this study the development of sporophytes in tissue culture was unreliable, although sometimes high (data not presented). Willyams and Daws (2014) also observed that sporophyte in vitro development in Austral Bracken from Western Australia varied between vessels and spore lines.

The approach of combining rapid gametophytic growth in vitro with the induction of the sporophytic stage in the nursery is based on Knauss (1976) who worked with maidenhair fern (Adiantum tenerum) and further adapted his method to ferns that produced only gametophytes in tissue culture. In vitro grown gametophytes were macerated in a blender and distributed onto potting mix in a mist house. This relatively simple method was later employed for the Southern African tree fern Cyathea dregei (Finnie and Van Staden 1987). In Austral Bracken however, this method resulted in poor sporophyte production (data not shown) which confirms the observations by Willyams and Daws (2014). As a consequence the system was altered by using small clumps instead of blended gametophytes thereby causing less 
disturbance to the gametophytes when being transferred from the Petri dishes to ex vitro conditions.

As many as 121 tubes (with multiple sporophytes) were produced in 13 weeks from two Petri dishes, despite fungal infections. This resulted from a cautious approach. When trays with sporophytes from the other trials were given to a local nursery for potting on, they reported having harvested between 230 and 500 plants per half-tray (Australian Ecosystems, pers. comm., 2013). Repeated tests showed that the time needed for a tray to be ready for potting could vary from 9 to 13 weeks. The partial tissue culture system was more productive and, most importantly, more reliable than a propagation system that relied purely on in vitro culture (Willyams and Daws 2014).

Coir, in a blend with pine bark based potting mix, provided an environmentally sustainable alternative to peat. Plants grew more vigorously in pots that had a higher water holding capacity and allowed some horizontal growth of the rhizomes than in forestry tubes (usually favoured for field planting). Willyams and Daws (2014) also found that the larger the pot, the higher sporophyte survival during greenhouse acclimatisation of in vitro plants.

This paper further reports on the first field plantings of in vitro derived Austral Bracken. Monitoring of field plantings after the first few months showed high survival and active growth.

The partial tissue culture system described here allows for the reliable large-scale propagation of Austral Bracken when spores are scarce. The in vitro propagation of gametophytes by tissue culture laboratories is very fast and cultures can easily be shipped to ferneries for further production. Because of its simple design and low cost it has potential for the commercial production of this species. Future studies could investigate the use of gametophyte beads for direct sowing as is currently being trialled in England for restoring peat land habitat (Moors for the Future Partnership, 2012).

\section{References}


Australian Plants Society Maroondah Inc. (2001) Flora of Melbourne: a guide to the indigenous plants of the greater Melbourne area. Hyland House Publishing Pty Ltd, Melbourne.

Barnicoat H., Cripps R., Kendon J. and Sarasan V. (2011) Conservation in vitro of rare and threatened ferns - case studies of biodiversity hotspot and island species. In Vitro Cellular and Developmental Biology Plant 47, 37-45.

Cardinia Shire Council (2015) Southern Brown Bandicoot. Indigenous plants suitable for bandicoots. URL: Available from http://www.cardinia.vic.gov.au/Page/Page.aspx?Page_id=5110 [Verified 6 October 2015]

Dyer A.F. (1989) Does bracken spread by spores? Bracken Biology and Management. Paper from an International Conference. Bracken 89. University of Sydney, 18-21 July 1989. (eds J.A. Thomson and R.T. Smith)

Fernandez H. and Revilla M.A. (2003) In vitro culture of ornamental ferns. Plant Cell, Tissue and Organ Culture 73, 1-13.

Finnie J.F. and van Staden J. (1987) Multiplication of the Tree Fern Cyathea dregei. HortScience 22, 665.

Jones D.L. (1987) Encyclopaedia of ferns. Lothian Book, Melbourne.

Jones DL, Clemesha SC (1980) Australian ferns and fern allies, $2^{\text {nd }}$ Edition. Reed Books, Sydney.

Knauss J.F. (1976) A partial tissue culture method for pathogen-free propagation of selected ferns from spores. Proc.Fla.State Hort.Soc. 89, 363-365.

Low V.H.K. and Thomson J.A. (1990) Cyanogenesis in Australian bracken (Pteridium esculentum): distribution of cyanogenic phenotypes and factors influencing activity of the cyanogenic glucosidase. In: Bracken Biology and Management. (eds J.A. Thomson and R.T. Smith) pp 105-111. The Australian Institute of Agricultural Science, Sydney.

McGlone M.S., Wilmhurst J.M. and Leach H.M. (2005) An ecological and historical review of bracken (Pteridium esculentum) in New Zealand and its cultural significance. New Zealand Journal of Ecology 29, 165-184. 
Menendez V., Arbesu R., Somer M., Revilla A. and Fernandez H. (2011) From spore to sporophyte: how to proceed in vitro. In: Working with ferns: issues and applications. (eds $\mathrm{H}$. Fernandez) pp. 97-110. Springer, New York.

Moors for the future partnership (2012) Millions of moss beads airlifted to restore Peak District and South Pennine moors. Available from URL:

http://www.moorsforthefuture.org.uk/node/546 [Verified 15.February 2016]

Murashige T. and Skoog F. (1962) A revised medium for rapid growth and bio-assays with tobacco callus culture. Physiologia Plantarum 15, 473-497.

Sarasan V., Cripps R., Ramsay M., Atherton C., McMichen M., Prendergast G. and Rowntree J. (2006) Conservation in vitro of threatened plants - progress in the past decade. In Vitro Cell. Dev. Biol.-Plant 42, 206-214.

Smith B.L., Seawright A.A., Ng J.C., Hertie A.T., Thomson J.A. and Bostock P.D. (1994) Concentration of Ptaquiloside, a major carcinogen in bracken fern (Pteridium spp.9; from Eastern Australia and from a cultivated worldwide collection held in Sydney, Australia. Natural Toxins 2, 347-353.

Somer M., Arbesu R., Menendez V., Revilla M.A. and Fernandez H. (2010) Sporophyte induction studies in ferns in vitro. Euphytica 171, 203-210.

Thomson J.A., Willoughby C. and Shearer C.M. (1986) Factors affecting the distribution, abundance and economic status of bracken (Pteridium esculentum) in New South Wales. In: Bracken: Ecology land use and control technology: proceedings on the international conference, Bracken 85. (eds R.T. Smith and J.A. Taylor) pp. 109-119. The Parthenon Publishing Group Ltd, Carnforth.

Willyams D. and Daws M.I. (2014) Mass propagation of Austral Bracken fern (Pteridium esculentum) sporophytes from in vitro gametophyte cultures. South African Journal of Botany 91, 6-8.

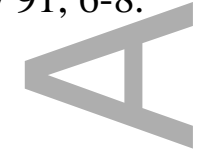

Tab. 1: The reliability of the partial tissue culture system to produce Austral Bracken sporophytes over different seasons and from different populations is shown here: Mean percentage of gametophyte explants producing sporophytes from eight different trials 
initiated in the fog house between April and November 2013 and the days elapsed from the initiation date to their transfer to the greenhouse and the final evaluation. (Replications $=$ half trays as depicted in Appendix 2a.)

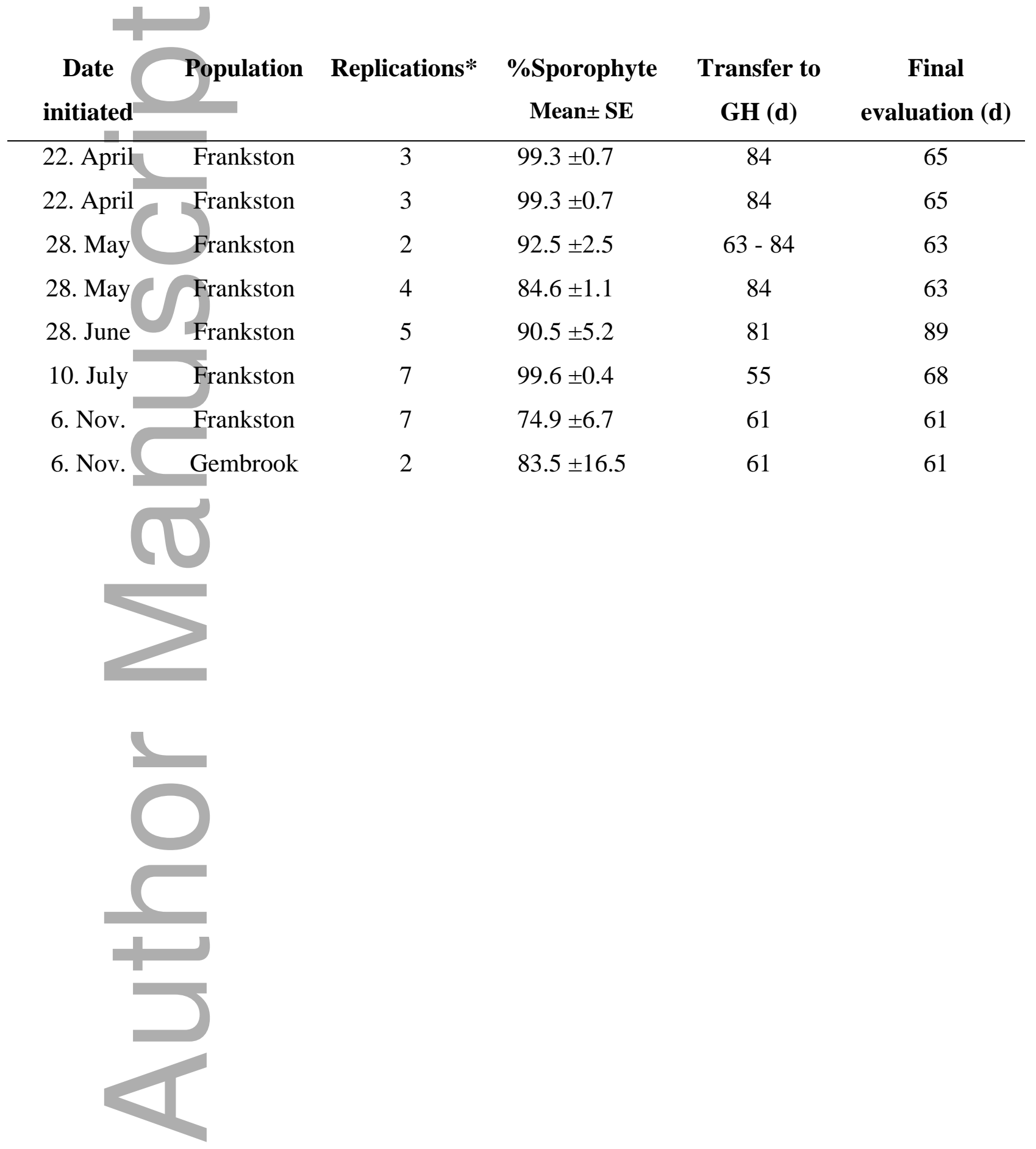




\section{University Library}

\section{- M M N E R VA A gateway to Melbourne's research publications}

Minerva Access is the Institutional Repository of The University of Melbourne

Author/s:

Kodym, A;Lang, M;Delpratt, J

Title:

Propagation by partial tissue culture of Austral Bracken (Pteridium esculentum) for revegetation

Date:

2016-05-01

Citation:

Kodym, A., Lang, M. \& Delpratt, J. (2016). Propagation by partial tissue culture of Austral Bracken (Pteridium esculentum) for revegetation. ECOLOGICAL MANAGEMENT \& RESTORATION, 17 (2), pp.159-163. https://doi.org/10.1111/emr.12209.

Persistent Link:

http://hdl.handle.net/11343/291264 